\title{
PELAKSANAAN BIMBINGAN KONSELING DI TKLB B/C AL AZHAR WARU SIDOARJO
}

\author{
Dian Puspa Dewi \\ Dosen PG-PAUD FKIP Universitas Adi Buana Surabaya \\ dianpuspadewi90@gmail.com
}

\begin{abstract}
ABSTRAK
Bimbingan dan konseling merupakan proses bantuan psikologis dan kemanusiaan secara ilmiah serta professional yang diberikan oleh pembimbing/ konselor secara optimal, yaitu mampu memahami diri dan mengaktualisasikan diri, sesuai tahap perkembangan, sifat-sifat potensi yang dimiliki dan latar belakang kehidupan serta lingkungannya. Bimbingan konseling memberikan pelayanan kepada semua kliennya tanpa memandang latar belakang kliennya terkait dengan siapa dan bagaimana keadaan kliennya. Anak berkebutuhan khusus adalah anak yang memiliki kebutuhan khusus sesuai dengan kriteria kecacatannya. Anak berkebutuhan khusus merupakan individu yang berbeda dari anak normal pada umumnya, baik secara intelektual, fisik, emosi dan sosial. Mereka, memiliki beragam masalah terkait dengan kecacatan yang dimilikinya. Bimbingan konseling dalam pelaksanaan di sekolah khususnya di TKLB yang menangani peserta didik berkebutuhan khusus sangat diperlukan keberadaanya. Untuk membantu menangani permasalahan $\mathrm{ABK}$ yang jauh lebih kompleks dibandingkan dengan masalah anak normal pada umumnya. Namun sayangnya, penulis melihat praktek pelaksanaan Bimbingan dan konseling di salah satu TKLB di Sidoarjo Jawa Timur yaitu TKLB BC Al Azhar Sidoarjo masih belum melaksanakan bimbingan konseling dengan baik. Pelaksanaan bimbingan konseling di TKLB ini dilaksanakan oleh guru dan kepala sekolahnya. Belum ada konselor yang menangani permasalahan $\mathrm{ABK}$ tersebut. Pihak sekolahlah yang berperan dalam penyeselesaian masalah siswa.
\end{abstract}

Kata kunci : Bimbingan Konseling 


\section{A. Latar Belakang}

Bimbingan dan Konseling merupakan satu kesatuan usaha yang diberikan pada mereka yang membutuhkan bantuan untuk mencegah atau membantu mengatasi masalah yang dihadapi. Usaha ini dilakukan oleh seorang yang professional, seseorang yang memberikan bantuan ini disebut konselor. Konselor membantu kliennya untuk menyelesaikan masalah yang dihadapi dengan beberapa prosedur dan aturan yang apik.

Klien dalam bimbingan dan konseling tidak berdasarkan pada kriteria tertentu, maksudnya klien bimbingan dan konseling mencakup semua individu dengan keadaan dan permasalahan apapun. Tidak berusaha membedakan kilen dan berusaha memberikan pelayanan dan bantuan yang sama sesuai dengan keadaan dan permasalahan individu tersebut.

Bimbingan dan Konseling pada umumnya berada di satuan pendidikan seperti di sekolah. Satuan pendidikan contohnya di SMP dan SMA, untuk satuan pendidikan SD sebagian besar masih belum menerapkan bimbingan dan konseling di lingkungannya, tapi ada beberapa yang sudah diterapkan dan dilaksanakan dengan baik. Peran bimbingan konseling di dalam pendidikan ialah membantu anak-anak dalam menghadapi masalah yang dihadapinya dalam kegiatan pembelajaran di kelas, sosialisasi dengan teman sebayanya, pengemangan bakat, minat, dll. Juga untuk berusaha mencegah anak-anak agar tidak dapat terjerumus ke dalam tindakan yang tidak diinginkan misal bolos sekolah, mencuri, merokok, dll.

Guru bimbingan dan konseling selalu berusaha membantu kliennya yang dalam hal ini adalah anak-anak dengan mengadakan pendekatan yang sesuai dengan keadaan dan permasalahan anak. Pemberian bantuan dan pencegahan dilakukan dengan berbagai macam cara dan metode agar dapat masuk ke dalam permasalahan anak, dengan nantinya mencari jalan keluar bersama dengan anak dengan anak yang memutuskan pengambilan sikap untuk menyelesaikan masalahnya.

Sekolah Luar Biasa atau TKLB adalah sekolah khusus yang melayani kebutuhan bidang pendidikan bagi Anak berkebutuhan khusus (ABK). TKLB merupakan satuan pendidikan yang memiliki peserta didik khusus dengan permaslahan dan kebutuhan yang khusus pula. Seperti yang disebutkan di atas bahwa bimbingan dan konseling ada pada satuan pendidikan seperti SD, SMP dan SMA. TKLB sebagai bagian dari satuan pendidikan memerlukan pula peran Bimbingan dan konseling dalam menangani permasalah anak berkebutuhan khusus. 
Anak berkebutuhan khusus adalah anak yang memiliki kebutuhan dan permasalahan khusus jika dibandingkan anak lainnya. Anak berkebutuhan khusus sangat memerlukan bantuan dalam menangani permasalahan yang dihadapinya dan dalam mencegah masalah yang mungkin akan terjadi di kemudian hari. Bimbingan konseling yang memberikan bantuan dalam menyelesaikan masalah kliennya agaknya dapat sangat bermanfaat jika BK ada dan dilaksanakan di sekolah luar biasa untuk menangani setiap permasalahan yang sedang dihadapi anak berkebutuhan khusus dan mencegah masalah yang belum dihadapi dan kemungkinan akan dihadapi anak berkebutuhan khusus di kemudian hari. Mengingat bahwa bimbingan konseling tidak memandang setiap kiliennya berdasarkan masalah khusus yang dimiliki kliennya.

Adapun Rumusan masalah penelitian ini adalah Bagaimana pelaksanaan Bimbingan Konseling di TKLB B/C Al AZHAR Waru Sidoarjo?

\section{B. Kajian Pustaka}

1. Bimbingan dan Konseling

a. Pengertian

Banyak ragam definisi yang bisa diangkat tentang bimbingan. Satu definisi bimbingan yang diangkat disini ialah bahwa " bimbingan adalah proses membantu individu untuk mencapai perkembangan optimal." Definisi ini memiliki makna bahwa:

1) Bimbingan adalah suatu proses. Sebagai suatu proses bimbingan merupakan kegiatan yang berkelanjutan, berlangsung terus menerus dan bukan kegatan seketika atau kebetulan. Bimbingan adalah kegiatan yang sistematis dan berencana yang terarah kepada pencapaian tujuan dan bukan kegiatan sewaktu-waktu atau insidential.

2) Bimbingan adalah bantuan. Maksudnya adalah mengembangkan lingkungan yang kondusif bagi perkembangan siswa, memberikan dorongan dan semangat, menumbuhkan keberanian bertindak bertanggung jawab, mengembangkan kemampuan untuk memperbaiki dan mengubah perilakunya sendiri.

Sedangakan Konseling berasal dari bahasa latin yaitu"consilium" yang artinya dengan atau bersama, yang dirangkai dengan "menerima atau memahami". Sedangkan dalam bahasa Anglo-saxon konseling berasal dari "sellan" yang artinya menyerahkan atau menyampaikan. (Prayitno dan Erman. 2008:99)

Konseling sendiri memiliki pengertian yaitu proses pemberian bantuan yang dilakukan melalui wawancara konseling oleh seorang ahli 
(disebut konselor) kepada individu yang sedang mengalami suatu masalah (disebut klien) yang bermuara pada teratasinya masalah yang dihadapi klien. (Prayitno dan Erman. 2008:105) Sedangkan pengertian bimbingan konseling sendiri menurut SK Mendikbud Nomor 025/ D/ 1995, Bimbingan dan konseling adalah pelayanan bantuan untuk peserta didik, baik secara perorangan maupun kelompok agar mandiri dan berkembang secara optimal dalam bimbingan pribadi, bimbingan sosial, bimbingan belajar dan bimbingan karir melalui berbagai jenis layanan dan kegiatan pendukung berdasarkan norma yang berlaku. (Tim MGMP MTS Kabupaten Ngawi. 2012 : 5)

Pegertian Bimbingan dan konseling adalah proses bantuan psikologis dan kemanusiaan secara ilmiah serta professional yang diberikan oleh pembimbing/ konselor secara optimal, yaitu mampu memahami diri dan mengaktualisasikan diri, sesuai tahap perkembangan, sifatsifat potensi yang dimiliki dan latar belakang kehidupan serta lingkungannya.

b. Tujuan Bimbingan konseling

Tujuan bimbingan adalah perkembangan optimal. Maksudnya perkembangan yang sesuai dengan potensi dan sistem nilai tentangkehidupan yang baik dan benar. Perkembangan optimal bukanlah semata-mata pencapaian tingkat kemampuan intelektual yang tinggi, yang ditandai dengan penguasaan pengetahuan dan keterampilan, melainkan suatu kondisi dinamik dimana individu mempu mengenal dan memahami diri, berani menerima kenyataan diri, mengarahkan diri sesuai dengan kemampuan, kesempatan dan system nilai, melakukan pilihan dan mengambil keputusan atas tanggung jawab sendiri.

c. Prinsip-Prinsip Umum Bimbingan

1) Bimbingan diberikan kepada individu yang sedang berada dalam proses berkembang. Ini berarti bahwa bantuan yang diberikan kepadda siswa harus bertolak dari perkembangan dan kebutuhan siswa. Pembimbing bertugas untuk membantu siswa memahami system nilai sebagai bagian dari proses pengembangan dirinya.

2) Bimbingan diperuntukan bagi semua siswa. Ini berarti bahwa pembimbing perlu memahami perkembangan dan kebutuhan siswa secara menyeluruh, dan menjadikan perkembangan dan kebutuhan siswa tersebut sebagai salah satu dasar bagi penyusunan program bimbingan di sekolah. Prinsip ini juga mengandung arti bahwa pemberian bantuan kepada siswa tidak menunggu munculnya massalah pada siswa melainkan diarahkan kepada upaya mencagah 
munculnya masalah dan mengembangkan kemampuan siswa untuk menyelesaikan masalah sendiri.

3) Bimbingan dilaksanakan dengan mempedulikan semua segi perkembangan siswa. Ini berarti bahwa dalam bimbingan semua segi perkembangan siswa baik fisik, mental dan social maupun emosional dipandang sebagai satu kesatuan dan saling berkaitan.

4) Bimbingan berdasarkan pada pengakuan atas kemampuan individu untuk menentukan pilihan. Ini mengandung makna bahwa setiap siswa memiliki kemampuan untuk menentukan pilihan sendiri tentang apa yang akan dia lakukan. Pembimbing tidak emilihkan sesuatu untuk siswa melaikan membantu mengembangkan kemampuan siswa untuk melakukan pilihan.

5) Bimbingan adalah bagian terpadu dari proses pendidikan. Proses pendidikan bukanlah proses pengembangan aspek intelektual semata, melainkan proses pengembangan seluruh aspek kepribadian siswa. Ini berarti bahwa didalam praktek pendidikan tidak cukup hanya melaksanakan proses pembelajaran yang lebih banyak terpokus kepada membantu siswa menguasai pengetahuan secara intelektuan melainkan juga harus disertai dengan pengembangan aspek lain seperti keterampilan social, kecerdasan emosional, disiplin diri, pemahaman nilai, sikap dan kebiasaan belajar.

6) Bimbingan dimaksudkan untuk membentu siswa merealisasikan dirinya. Ini berarti bahwa bantuan di dalam proses bimbingan diarahkan untuk membantu siswa memahami dirinya, mengarahkan diri kepada tujuan yang realistic dan mencapai tujuan yang realistic itu sesuai dengan kemampuan diri dan peluang yang di peroleh.

d. Asas-asas Bimbingan Konseling

Sebagai sebuah pekerjaan yang professional Bimbingan Konseling harus dilaksanakan dengan mengikuti kaidah-kaidah yang menjanmin efisien dan efektivitas proses dan lain-lainnya. Kaidah-kaidah tersebut dikenal dengan asas-asas dalam bimbingan dan konseling. Asas-asas bimbingan dan konseling adalah:

1) Asas kerahasiaan, dimana segala sesuatu yang dibicarakan kepada konselor tidak boleh diceritakan kepada pihak lain. Asas kerahasiaan merupakan kunci dalam usaha bimbingan dan konseling,

2) Asas kesukarelaan, proses bimbingan harus berjalan secara sukarela dimana si klien dengan sukarela menceritakan masalahnya 
tanpa paksaan dan ragu-ragu sedangkan konselor juga harus secara sukarela dalam membantu klien,

3) Asas keterbukaan, dimana antara konselor dank lien harus samasama terbuka selama proses bimbingan untuk sama-sama memecahkan masalah yang dihadapi klien. Terbuka terkait dengan masalah yang dihadapi klien dan konselor secara terbuka memberikan jalan keluar,

4) Asas kekinian, masalah yang dihadapi klien merupakan masalah yang sedang terjadi dengan klien bukan masalah lampau dan yang akan dating. Selain itu yang dimaksud kekinian adalah konselor segera berusaha menyelesaikan masalah klien tidak menundanunda,

5) Asas kemandirian, bimbingan konseling ini bertujuan agar si klien dapat berdiri sendiri dan tidak bergantung dengan konselor

6) Asas kegiatan. dimana dalam proses bimbingan dan konseling klien diusahakan untuk mampu melakukan kegiatan yang berkaitan dengan pemecahan masalah yang dihadapinya,

7) Asas kedinamisan, dimana proses bingan dan konseling mengacu pada hal-hal baru yang hendaknya terdapat pada dan menjadi cirri-ciri dari proses konseling dan hasilhasilnya,

8) Asas keterpaduan, dimana pelayanan bimbingan konseling berusaha memadukan aspek kepribadian klien, selain itu juga harus memperhatikan keterpaduan isi dan proses layanan,

9) Asas kenormatifan, pelayanan bimbingan dan konseling tidak boleh bertentangan dengan normanorma yang berlaku seperti norma agama, norma adat, norma ilimu, dll,

10) Asas keahlian, pemberian layanan bimbingan konseling harus memperhatikan kulifikasi konselor yang dapat memadukan teori dan praktek yang baik,

11) Asas alih tangan, pelayanaanakan di laih tangankan kepada petugas atau badan yang lebih ahli jika konselor telah berusaha mengerahkan segenap usahanya dalam membantu masalah kliennya

12) Asas tut wuri handayani, dimana proses bimbingan dan konseling ini dapat dirasakan manfaatkan tidak hanya saat proses bimbingan berjalan namun di luar proses bimbingan dan konseling pun masih dapat dirasakan manfaatnya.

Asas-asas dalam bimbingan dan konseling harus dapat dipatuhi dalam melaksanakan bimbingan kionseling terhadap klien. 
2. Permasalahan Anak Berkebutuhan Khusus

Anak berkebutuhan khusus adalah anak yang meiliki pelayanan yang khusus sesuai dengan kebutuhannya. Anak berkebutuhan khusus terdiri dari berbagai jenis yaitu: Tunanetra, Tunarungu, Tunagrahita, Tunadaksa, Tunalaras, Kesulitan belajar, dll. Masing-masing jenis ketidakmampuan anak tersebutpun memiliki kebutuhan masing-masing yang harus dipenuhi. Selain memperhatikan masalah kebutuhannya, kita juga perlu memperhatikan permasalahan anak berkebutuhan khusus terkait ketidakmampuan atau kebutuhan khususnya. Masalah yang dihadapi anak berkebutuhan khusus satu sama lain berbeda. Namun adalah masalah-masalah yang pasti dihadapi ABK terkait dengan kebutuhannya. Masalah yang secara umumterjadi pada anak berkebutuhan khusus akan dipaparkan sebagai berikut:

a. Masalah pendidikan dan pengajaran

Masalah yang dihadapi awal masuk sekolah yaitu: menyesuaikan diri dengan lingkungan sekolah, guruguru dan staff sekolah, teman-teman, mata pelajaran baru, tata tertib dsb. Setelah selesai sekolah anak mulai lagi dihadapkan dengan masalah untuk melanjutkan studi dan mencari pekerjaan yang sesuai dengan keadaan dan kemampuannya.
Dalam kegiatan pembelajaran anak mengalami permasalahan antara lain pada masalah media pembelajaran yang digunakan, penyamapaian materi, kurikulum yang diberikan pada $\mathrm{ABK}$, modifikasi waktu belajar dll.

b. Masalah sosial dan penyesuaian diri Banyak anggapan dengan ketidakmampuan anak berkebutuhan khusus maka hilanglah kemampuan seseorang sehingga hal ini dapat berpengaruh terhadap kepribadian anak berkebutuhan khusus yang dapat berakibat berubahnya konsep dirinya, sehingga mereka merasa rendah diri terhadapa orang lain karena keterbatasannya itu. Dengan demikian dapat berpengaruh terhadap kehidupan dan dalam menyesuaikan diri kepada keadaan dan tuntutan sekolah, keluarga dan juga dirinya sendiri.

c. Masalah keterampilan dan pekerjaan Mengingat keterbatasan yang dimiliki anak berkebutuhan khusus, maka penting sekali adanya identifikasi terhadap jenis-jenis keterampilan dan pekerjaan yang ada di masyarakat, juga perlu diketahui kemampuankemampuan apa yang dimiliki indvidu yang cocok dengan keterampilan dan pekerjaan yang ada di masyarakat serta usaha-usaha pemilihan latihan-latihan untuk keterampilan dan pekerjaan tertentu.

d. Masalah ketergantungan diri

Masalah ini dapat saja muncul karena disamping 
ketidakmampuapnnya mengatasi masalahnya sendiri dapat juga kurangnya kepercayaan terhadap dirinya sendiri. Sehingga dapat muncul masalah-masalah ketergan-tungan dirinya kepada orang lain dan selalu merasa tidak mampu mengatasi kesulitan dirinya sehingga cenderung untuk mengharapkan bantuan pertolongan kepada oranglain.

e. Masalah penggunaan waktu senggang

Anak berkebutuhan khusus sama halnya dengan orang normal, pastinya memiliki waktu luang dalam hari-harinya. Dengan keterbatasan yang dimilikinya anak berkebutuhan khusus lebih banyak yang menggunakan waktunya tersebut untuk berada di rumah saja karena mungkin malu dengan lingkungannya. Seharusnya anak berkebutuhan khusus dapat memanfaatkan waktu luang tersebut untuk kegiatan yang produktif, dengan bantuan dari orang disekitarnya yang memfasilitasi.

f. Masalah gangguan kepribadian dan emosi.

Memahami akan karakteristik masing-masing anak berkebutuhan khusus, nampak jelas adanya masalah dalam hal kemampuan berpikir, keseimbangan kepribadian-nya kurang konstan atau labil, kadang-kadang stabil dan kadang pula kacau, dll.

\section{Hasil Penelitian}

TKLB BC Al Azhar Sidoarjo adalah sekolah luar biasa yang menangani anak berkebutuhan khusus tipe B (Tunarungu) dan C (Tunagrahita). Namun, di luar itu TKLB BC Al Azhar Sidoarjo juga menerima anak berkebutuhan khusus dengan jenis kebutuhan khusus lain yaitu celebral palsy, autis, hiperaktif. TKLB ini terdiri dari jenjang pendidikan TK dan SD. TKLB ini di kepala sekolahi oleh Bapak Agus Purwanto, S.Pd. TKLB BC Al Azhar memiliki peserta didik berkebutuhan khusus yang beragam dengan karakteristik dan kebutuhan masingmasing.

Peneliti melakukan pengamatan di TKLB ini terhadap pelaksanaan bimbingan konseling. Hasil dari penelitian penulis adalah TKLB BC Al Azhar ini belum melaksanakan bimbimngan konse-ling dengan baik. Tidak ada konselor di TKLB tersebut. Peran konselor yang memberikan bimbingan kepada siswa berkebutuhan khusus menjadi tanggung jawab semua guru dan kepala sekolah. Kepala sekolah memiliki multirole di TKLB ini terkait dengan pelaksanaan bimbingan konseling.

Seperti yang disebutkan di atas, bahwa peserta didik berkebutuhan khusus di TKLB ini memiliki karakteristik dan kebutuhan yang berbeda satu sama lain. Pemberian bantuan dan bimbingan pun sebaiknya 
diberikan secara berbeda kepada mereka. Di TKLB ini bimbingan diberikan kepada guru kelas kepada siswanya masing. Bimbingan yang terkait dengan bimbingan belajar dna yang terkait dengan siswa dalam kelas dilakukan oleh guru. Kepala sekolah memberikan teguran pada siswa yang melakukan pelanggaran-pelanggaran dan yang melakukan perilaku tidak sewajarnya.

Selain beragam dalam masalah kebutuhan dan karakteristiknya, peserta didik berkebutuhan khusus di sekolah ini juga beragam dalam usia kronologisnya. Ada yang sudah berusia puluhan tahun. Secara biologis, dengan usia puluhan tahun itu anak sudah mulai tertarik dengan lawan jenis dan dengan pemenuhan kebutuhan biologisnya. Anak yang dengan keadaan mentalnya dapat melakukan apa saja yang menurut mereka "mengasyikan" menurut mereka secara biologis. Terjadi kejadian dimana ada salah siswa wanita yang sduah berusia lebih dari 20 tahun berciuman dengan siswa laki-laki dengan usia yang kurang lebih sama di belakang sekolah. Hal itu dilakukan secara sembunyisembunyi dari guru dan pihak sekolah yang lain. Hal yang semacam itu semestinya memerlukan bimbingan seksiologi dari pihak yang ahli. Sejauh ini peran guru dan kepala sekolah hanya menasehati dan berusaha mengawasi anak tersebut.
Berbagai permasalahan yang terjadi pada peserta didik berkebutuhan khusus di TKLB ini sangat beragam. Oleh karena itu, perlu penanganan yang sesuai juga dengan kebutuhan siswa. Bimbingan konseling dalam hal ini sangat diperlukan, mengingat masalah dalam TKLB lebih kompleks daripada sekolah umum. Penanganan yang diberikan juga beragam, berbeda antar satu siswa dengan siswa lainnya. Penanganan yang diberikanpun sebaiknya juga harus melibatkan pihak guru dan kepala sekolah, dan juga pihak orangtua. Kerja sama dengan pihak yang dekat dan mengerti keadaan anak sangat diperlukan, agar penanganan terhadap anak dapat sesuai dengan yang dibutuhkannya.

\section{Pembahasan}

Berdasarkan hasil penelitian yang telah dilakukan diperoleh hasil bawha di TKLB B/C Al Azhar WaRU Sidoarjo ini pelaksanaan Bimbingan Konseling masih belum terlaksana. Hal ini dikarenakan belum adanya konselor yaitu tenaga khusus yang memiliki kelimuan Bimbingan Konseling atau Psikologi untuk mennagani permasalahan anak.

Bimbingan konseling ialah proses bantuan terhadap individu untuk mencapai pemahaman dan pengarahan diri yang dibutuhkan untuk melakukan penyesuaian diri secara maksimal terhadap keluarga, sekolah serta 
masyarakat. Peranan bimbingan konseling bagi anak berkebutuhan khusus ialah agar mereka dapat dan mampu menyesuaikan diri dengan lingkungannya sehinga mereka dapat mempersiapkan dan melakukan tugasnya sebagai salah seorang warga masyarakat sekolah dan masyarakat luas.

Untuk mencapai tujuan tersebut peranan konselor cukup besar. Oleh karena itu pembimbing diharapkan berfungsi sebagai :

1. Sumber informasi, informasi konselor hendaknya tidak hanya ditunjukan bagi siswa itu sendiri, akan tetapi juga selayaknya ditunjukan kepada orang tua siswa dan masyarakat luas sehingga semua pihak mempunyai pemahaman dan harapan yang realistik terhadap siswa berkebutuhan khusus, dan juga bagi anak itu sendiri. Informasi yang benar dari konselor akan sangat membantu mereka dalam menghadapi problem anak. Banyak orang tua dan anak yang menjadi bingung, menunjukan kecemasan dan kekhawatiran yang belebihan menghadapi musibah kecacatan. Mereka bingung dalam merencanakan dan menentukan masa depan mereka. Pembimbing diharapkan dapat memainkan perannya secara bijaksana.

2. Fasilitator yaitu pemberi kemudahan dalam mengatasi masalah yang dihadapi oleh siswa. Konselor bersama dengan siswa harus dapat menunjukan dan menemukan cara memecahkan masalah, menujukan dimana alat dan fasilatas diperlukan mungkin dperoleh, dan lembaga mana yang dapat dihubungi untuk diajak bekerjasama memecahkan berbagai macam pesoalan.

3. Mediator yang dapat dan mau mengerti sepenuhnya kehidupan siswa, dan problema-problema yang meeka hadapi. Konselor diharapkan dapat menuntun para siswa dalam menemukan kebutuhankebutuhannya, serta menari alternatif pemecahan dan jalan keluar.

4. Sumber kasih sayang bagi siswa, sehingga siswa akan tumbuh menjadi pribadi yang stabil, matang dan mantap.

Demikian besar peran konselor dalam rangka membanu siswa, oleh karena itu sangat diharapkan agar konselor memberikan layanan kepada siswa secara terencana, tearah dan terus menerus agar mampu mengantarkan mereka untuk berdiri dengan kaki sendiri ditengah-tengah masyarakat.

Konselor selain memiliki peran di atas juga memiliki peranan dalam memberikan bimbingan keada Anak berkebutuhan khusus. Anak berkebutuhan khusus memerlukan bimbingan dan konseling, bahkan berbagai jenis bimbingan. Bimbingan 
yang dimaksud adalah bimbingan pemeliharaan kesehatan fisik, bimbingan belajar, bimbingan penyesuaian diri dan bimbingan jabatan atau lebih khusus lagi bimbingan kerja.

\section{Bimbingan fisik}

Anak berkebutuhan khusus yang mengalami kecacatan fisik (tunanetra, tunarungu, tunadaksa, cacat mantal dan tunalaras) fisiknya harus dijaga agar tetap sehat dan terawat dengan baik. Hal ini semakin dirasakan pentingnya bila kita semua ingat satu prinsip yang mengatakan bahwa terdapat hubungan yang erat antara gangguan dalam segi pisik dengan yang bersifat psikis.

\section{Bimbingan belajar}

Bimbingan belajar di berikan kepada anak berkebutuhan khusus pada umumnya, khususnya kepada siswa yang pada suatu saat membutuhakan bantuan untuk memecahkan masalah atau kesulitan yang berhubungan dengan kegiatan belajar, baik itu disekolah, di asrama, di luar sekolah ataupun di luar asrama.

\section{Bimbingan penyesuaian diri}

Penyesuaian diri merupakan salah satu tugas perkembangan siswa. Siswa dituntut untuk dapat menyesuaikan dirinya, baik dengan dirinya sendiri, dengan keluarga, dengan lingkungan sekolah, dengan teman sebaya dan dengan masyarakat luas.
Penyesuaian dengan diri sendiri berarti bahwa anak berkebutuhan khusus mampu betindak dan bercitacita sesuai dengan keadaan, ketertiban dan kemampuan dirinya, seta dapat membina kehidupan pribadi yang sehat baik: jasmani, maupun rohani.

Penyesuaian dengan keluarga berarti bahwa anak berkebutuha khusus ini, dengan kecacatan yang disandangnya diharapkan akan mampu bergaul secara harmonis dengan dengan orang tua dan dengan saudarasaudaranya atau anggota keluarga lain. Anak ini diharapkan tidak mengasingkan diri, tidak telampau tergantung kepada anggota keluarga yang lain, tidak selalu ingin menjadi pusat perhatian orang lain, akan tetapi justru ia dapat memahami kedudukan dan tanggung jawab sebagai salah satu anggota keluarga.

Penyesuain diri dengan sekolah berarti bahwa anak berkebutuhan khusus harus mampu menyesuaikan diri dengan tata tertib sekolah, bersikap hormat terhadap guru dan personl lainnya, serta mampu mengerjakan tugas dan bergaul secara harmonis dengan teman-temannya.

Penyesuaian dengan masyarakat berarti bahwa anak berkebutuhan khusus harus mampu berada dalam masyarakat luas sebagai anggota biasa yang wajar, berprilaku sesuai dengan norma-norma yang dianut masyarakat, agama dan adat istiadat. 
4. Bimbingan vokasional

Bimbingan vokasional bagi anak berkebutuhan khusus terutama ditunjukan kepada penyiapanmereka dalam menentukan pilihan bijaksana tentang pekerjaan atau karier setelah mereka dididik atau dilatih dalam lembaga pendididkan khusus bekerja. Miasalnya: dengan latihan kerja di asrama, magang di kantor atau latihan secara khusus dibalai latihan kerja.

\section{E. Kesimpulan}

Pelaksanaan Bimbingan dan konseling di salah satu TKLB di Sidoarjo Jawa Timur yaitu TKLB BC Al Azhar Sidoarjo masih belum melaksanakan bimbingan konseling dengan baik. Pelaksanaan bimbingan konseling di TKLB ini dilaksanakan oleh guru dan kepala sekolahnya. Belum ada konselor yang menangani permasalahan ABK tersebut. Pihak sekolahlah yang berperan dalam penyeselesaian masalah siswa.

\section{F. Saran}

Berdasarkan hasil penga-matan yang dilakukan oleh penulis, dan ditemukan beberapa permasa-lahan dalam penerapan bimbingan konseling di TKLB BC Al Azhar Sidoarjo. Sehingga, penulis membe-rikan saran terkait dengan hal tersebut, yaitu:

1. Terkait dengan pelaksanaan bimbingan konseling di TKLB BC Sidoarjo, sebaiknya pihak sekolah dapat memikirkan untuk menghadirkan konselor dalam menangani masalah ABK,

2. Mengadakan pertemuan dan pembicaraan dengan komite sekolah dan pihak terkait mengenai pengadaan bimbingan dan konseling di TKLB tersebut.

\section{DAFTAR PUSTAKA}

ABKIN (2007). Naskah Akademik: Penataan Pendidikan Profesional Konselor dan Layanan Bimbingan dan Konseling Dalam Jalur Pendidikan Formal. Jakarta: Dirjen Dikti Depdiknas.

Achmad Shidiq Permana. 2011. Bimbingan Anak Berkebutuhan Khusus. Jawa Berat: http://achmadblue.blogspot.com/2 011/03/bimbingan-anakberkebutuhan-khusus.html (diakses 29 oktober 2012, 7.16 pm)

Prayitno dan Erman Amti. 2008. Dasar-dasar bimbingan dan konseling. Jakarta: Rineka Cipta

Somantri, S. (2007). Psikologi Anak Luar Biasa. Bandung: PT. Refika Aditama. 
Tim MGMP MTS Kabupaten Ngawi.

2012. Lks Cendekia. Bimbingan

Konseling. Ngawi: Anugrah

Agung 
